\title{
SANITATION AND HYGIENE AS FACTORS FOR CHOOSING A PLACE TO STAY: PERCEPTIONS OF THE BULGARIAN TOURISTS
}

This is a pre-publication version of Naumov, N., Varadzhakova, D. \& Naydenov, A. (2020). Sanitation and hygiene as factors for choosing a place to stay: Perceptions of the Bulgarian tourists. Anatolia, DOI: 10.1080/13032917.2020.1771742

To link to this article: https://doi.org/10.1080/13032917.2020.1771742

\section{INTRODUCTION}

In December 2019, a relatively unknown disease was detected in the city of Wuhan, the capital of the Chinese Hubei province. Identified as a new respiratory virus and largely defined as a novel type of coronavirus (Huang et al., 2020), what is known as SARS-CoV-2 but commonly referred as COVID-19, has spread worldwide with unprecedented speed and infection rate. The World Health Organisation (WHO) declared a global health emergency on $30^{\text {th }}$ January 2020 which further escalated to a worldwide global pandemic declared on $11^{\text {th }}$ March 2020 . At the time of writing in mid-May 2020, around 4.5 million infections had been reported with nearly 300, 000 cases with a fatal outcome (John Hopkins University, 2020).

Although the world has previously been exposed to notable epidemics/pandemics such as Ebola, severe acute respiratory syndrome (SARS) and Zika (Buheji \& Ahmed, 2020), none of them has had such a notorious and holistic impact on the world's economy and society. The OECD and the International Monetary Fund (IMF) have already warned that the overall economic impact is expected to be substantially higher that global financial crisis in 2008 (Hunt, 2020). The tourism industry has been one of the hardest hit by the disruption from the COVID-19 with the imposed restrictions on both international and domestic travel, and the immediate closure of hotels, restaurants and visitor attractions. According to UNWTO (2020), the industry is expected to decline by $20-30 \%$ with an anticipated loss of around US $\$ 300-450$ billion. As WHO currently "does not recommend any travel or trade restriction based on the current information available" (WHO, 2020), the tourism as we know it has disappeared and 'overtourism' (Milano, Cheer \& Novelli, 2019) has become 'non-tourism at all'. As Niewiadomski (2020) points out, the world is now experiencing a 'de-globalization' with around $90 \%$ of the world's population subject to a certain level of travel restrictions, imposed home-stay lockdowns or arrival quarantines (Gössling, Scott \& Hall, 2020).

As Novelli et al. (2018) argue, there is a limited academic scholarship on health-related crisis and their impact on the tourism industry, particularly in the developing world. Despite the notable and timely appearance of many studies focused on COVID-19 and tourism, the majority of them are conceptual in nature and more focused on the 'transformation' of tourism from a 
range of social science perspectives (see for example, Ateljevic, 2020; Brouder, 2020; Cheer, 2020; Higgins-Desbiolles, 2020; Nepal, 2020; Prideaux, Thompson. \& Pabel, 2020). Our paper focuses on another crucial dimension of the post COVID-19 era - the importance of safety, sanitation and hygiene in the context of tourism and hospitality and more specifically, sanitation measures as a decision-making factor for choosing an accommodation provider and willingness of the tourists to use their own sanitation products to ensure a good personal hygiene.

\section{METHODOLOGY}

Our research takes a quantitative approach in order to explore the importance of sanitation and willingness of the Bulgarian tourists to use their own sanitation products. The main research instrument is a self-administered survey which was distributed online from $13^{\text {th }}$ April to $20^{\text {th }}$ April 2020 to Bulgarian respondents aged 18+. In total, 656 anonymous responses were recorded and the sample covers the variety of the main population demographics such as gender, age, place of residence and education. The survey was distributed in Bulgarian and consisted of three main sections: introduction to the research aim and objectives, the main section with eleven closed-ended questions and a concluding section with seven questions about the demographic characteristics of the respondents. Most of the questions required a single answer but some of them permitted multiple answers, too. One third of the questions were measured on the ordinal scale, one question (age of the respondent) on the ratio scale and the rest of the variables were nominal.

The survey data have been processed using SPSS (ver. 26), including: the recoding of text answers, the scale definition, the verbatim coding of the open-ended questions, the data validation, the syntax programming, the frequency and cross tabulation. The tabulations were presented in absolute values and percentages in order to provide the basis for the further analyses and conclusions.

\section{RESULTS}

It is important to note that the travel intentions and preferences of Bulgarian tourists about the cleanliness and sanitation in accommodation establishments are researched at the beginning of the second month of emergency state in Bulgaria. Our results indicate that $42,1 \%$ of the respondents believe the peak of the outbreak is yet to come in Bulgaria and 40,5\% are not sure if the peak has already been reached or not.

A relatively high percent of respondents have indicated that they would prefer the comfort of staying at a family-owned (second home) apartment for their forthcoming holidays. This is largely consistent with the current state of emergency and motivated by the absence of clear legislative policy about the expected norms of sanitation and cleanliness. Interestingly, the second preference is $4 / 5$-star hotels, an option largely preferred by the respondents aged between $25-34(45 \%)$ whereas $41.6 \%$ of the same aged group have given a preference to second homes. 
The results also indicate another potentially interesting finding: a preference is given to guest houses than chain-branded hotels. $22.4 \%$ of the respondents would prefer to stay at a guest house and $18.8 \%$ would choose a branded property. Airbnb apartments, which are not so popular amongst Bulgarian population in general, would attract only $12.5 \%$ of the respondents. There is a gradual consistency in terms of age groups and gender (see Table 1).

\begin{tabular}{|c|c|c|c|c|c|c|}
\hline & \multirow{2}{*}{$\begin{array}{l}\text { All } \\
\text { respondents }\end{array}$} & \multicolumn{5}{|c|}{ Age } \\
\hline & & $18-24$ & 25-34 & 35-44 & $45-54$ & $55+$ \\
\hline $\begin{array}{l}\text { Accommodation at own } \\
\text { property }\end{array}$ & $47.9 \%$ & $51.4 \%$ & $41.6 \%$ & $46.7 \%$ & $51.1 \%$ & $54.5 \%$ \\
\hline $4 / 5^{*}$ hotel & $31.6 \%$ & $31.9 \%$ & $45.0 \%$ & $29.3 \%$ & $25.0 \%$ & $22.8 \%$ \\
\hline Guest house & $22.4 \%$ & $20.8 \%$ & $26.2 \%$ & $21.1 \%$ & $25.0 \%$ & $18.8 \%$ \\
\hline Chain-branded hotels & $18.8 \%$ & $23.6 \%$ & $24.2 \%$ & $20.2 \%$ & $13.0 \%$ & $8.9 \%$ \\
\hline Airbnb & $12.5 \%$ & $12.5 \%$ & $10.1 \%$ & $15.3 \%$ & $10.9 \%$ & $10.9 \%$ \\
\hline $1 / 2 / 3^{*}$ hotels & $9.0 \%$ & $8.3 \%$ & $11.4 \%$ & $9.9 \%$ & $4.3 \%$ & $7.9 \%$ \\
\hline $\begin{array}{l}\text { Camping } \\
\text { /caravan/campervan/tent }\end{array}$ & $1.5 \%$ & $0.0 \%$ & $2.0 \%$ & $2.9 \%$ & $0.0 \%$ & $0.0 \%$ \\
\hline Other & $1.2 \%$ & $0.0 \%$ & $0.0 \%$ & $1.7 \%$ & $1.1 \%$ & $3.0 \%$ \\
\hline Nowhere & $1.8 \%$ & $1.4 \%$ & $2.7 \%$ & $2.1 \%$ & $2.2 \%$ & $0.0 \%$ \\
\hline
\end{tabular}

Table.1 Accommodation place where to stay during vacation in 2020 regarding the trust in sanitary safety

The results also indicate that the sanitation and cleanliness at the accommodation establishments are key point of the tourists' preferences. More than $50 \%$ of the respondents plan to 'definitely' or 'more likely' use their own disinfectants to clean the guest rooms and bathrooms in their accommodation establishments. The women are more distrustful and $36,5 \%$ of them would clean their own guest rooms. $28 \%$ of the male respondents are concerned about cleanliness and would use additional sanitation. The age group of $55+$ is the dominant group here with $45,5 \%$ of our them expressing that they would 'definitely' will use additional disinfectants. They are followed by the age group of 18-24 years with 38,9\%. The results of our research do not demonstrate any correlation between the education level, the occupancy and the family status of the respondents and the use of additional disinfectants in the accommodation places.

\section{CONCLUSION}

Our research indicate that Bulgarian tourists do not generally trust the sanitation measures and 
cleanliness at rented places and there is an overall agreement that family-owned apartments and second homes would provide the best hygiene and sanitation comfort.

The high preference of the respondents to seek accommodation at guest houses rather than at chain-branded hotels could be motivated by their overall intention to spend their holidays in 2020 in Bulgaria $(61,4 \%)$ and to visit the Bulgarian Black Sea coast $(50,9 \%)$ where there is not so many international hotel chains. The other possible conclusion is that the guest houses are an expected to be less crowded than hotels and would thus provide a safer environment. The high percent of respondents who are willing to use additional disinfectants demonstrate the need of national and international standards of disinfections and sanitation at the accommodation establishments. Further empirical research is needed to explore the perception of tourists at a global scale as sanitation and hygiene are expected to become critical factors in the foreseeable future of tourism and hospitality.

\section{DISCLOSURE STATEMENT}

No potential conflict of interest was reported by the authors.

\section{REFERENCES}

Ateljevic, I. (2020). Transforming the (tourism) world for good and (re)generating the potential 'new normal', Tourism Geographies, https://doi.org/10.1080/14616688.2020.1759134

Brouder, P. (2020). Reset redux: possible evolutionary pathways towards the transformation of tourism in a COVID-19 world, Tourism Geographies, https://doi.org/10.1080/14616688.2020.1760928

Buheji, M., \& Ahmed, D. (2020). Foresight of Coronavirus (COVID-19) opportunities for a better world, American Journal of Economics, 10(2), 97-108. https://doi.org/ 10.5923/j.economics.20201002.05

Cheer, J. (2020). Human flourishing, tourism transformation and COVID-19: a conceptual touchstone, Tourism Geographies, https://doi.org/10.1080/14616688.2020.1765016

Gössling, S., Scott, D. \& Hall, C. M. (2020). Pandemics, tourism and global change: a rapid assessment of COVID-19, Journal of Sustainable Tourism, https://doi.org/10.1080/09669582.2020.1758708

Hall, C. M., Scott, D. \& Gössling, S. (2020). Pandemics, transformations and tourism: be careful what you wish for, Tourism Geographies, https://doi.org/10.1080/14616688.2020.1759131 
Higgins-Desbiolles, F. (2020). Socialising tourism for social and ecological justice after COVID19. Tourism Geographies. https://doi.org/10.1080/14616688.2020.1757748

Huang, C., Wang, Y., Li, X., Ren, L., Zhao, J., Hu, Y., Zhang, L., Fan, G., Xu, J., Gu, X., Cheng, Z., Yu, T., Xia, J., Wei, Y., Wu, W., Xie, X., Yin, W., Li, H., Liu, M., .. Cao, B. (2020). Clinical features of patients infected with 2019 novel coronavirus in Wuhan. The Lancet, 395(10223), 497-506. https://doi.org/10.1016/S0140-6736(20)30183-5

Hunt, R. (2020). The Economic effects of COVID-19 around the world. Available at: https://www.weforum.org/agenda/2020/02/coronavirus-economic-effects-globaleconomy-trade-travel/. Last accessed on 13 May 2020.

John Hopkins University (2020). COVID-19 Coronavirus pandemic. Available at: https://www.worldometers.info/coronavirus/\#countries. Last accessed on 14 May 2020.

Milano, C., Cheer, J., \& Novelli, M. (Eds.). (2019). Overtourism: Excesses, discontents and measures in travel \& tourism. Wallingford: CABI.

Nepal, S. (2020): Travel and tourism after COVID-19 - business as usual or opportunity to reset?, Tourism Geographies https://doi.org/10.1080/14616688.2020.1760926

Niewiadomski, P. (2020). COVID-19: from temporary de-globalisation to a rediscovery of tourism? Tourism Geographies, https://doi.org/10.1080/14616688.2020.1757749

Novelli, M., Gussing Burgess, L., Jones, A., Ritchie, B. (2018), 'No ebola. . .still doomed' - the ebola induced tourism crisis. Annals of Tourism Research, 70, 76-87.

Prideaux, B., Thompson, M. \& Pabel, A. (2020). Lessons from COVID-19 can prepare global tourism for the economic transformation needed to combat climate change, Tourism Geographies, https://doi.org/10.1080/14616688.2020.1762117

UNWTO. (2020). International tourist arrivals could fall by $20-30 \%$ in 2020 . Available at: https://www.unwto.org/news/international-tourism-arrivals-could-fall-in-2020. $\quad$ Last accessed on 13 May 2020.

WHO (2020). International health regulations (2005) emergency committee regarding the outbreak of novel coronavirus (2019-nCoV)". Available at: https://www.who.int/newsroom/detail/30-01-2020-statement-on-the-second-meeting-of-the-international-healthregulations-(2005)-emergency-committee-regarding-the-outbreak-of-novel-coronavirus(2019-ncov). Last accessed on 13 May 2020. 